\title{
Representing Punishments for Dirt-Eating and Intoxication in Richard Bridgens's West India Scenery, with Illustrations of Negro Character (1836)
}

\author{
Julia Skelly
}

Volume 36, numéro 2, 2011

URI : https://id.erudit.org/iderudit/1066743ar

DOI : https://doi.org/10.7202/1066743ar

\section{Aller au sommaire du numéro}

\section{Éditeur(s)}

UAAC-AAUC (University Art Association of Canada | Association d'art des universités du Canada)

\section{ISSN}

0315-9906 (imprimé)

1918-4778 (numérique)

Découvrir la revue

Citer cet article

Skelly, J. (2011). Representing Punishments for Dirt-Eating and Intoxication in Richard Bridgens's West India Scenery, with Illustrations of Negro Character (1836). RACAR : Revue d'art canadienne / Canadian Art Review, 36(2), 52-65. https://doi.org/10.7202/1066743ar

\section{Résumé de l'article}

Notre article se concentre sur l'étude de deux gravures de l'ouvrage West India Scenery dans lequel l'auteur, Richard Bridgens, a représenté des esclaves-dont certains récemment affranchis-qui sont punis pour avoir mangé de la terre et s'être intoxiqués. Bridgens désigne la consommation de terre comme une dépendance et une maladie en même temps, sans se donner la peine d'expliquer pourquoi les esclaves buvaient au point de s'intoxiquer, ni pourquoi l'ivresse était considérée comme punissable dans le contexte de la traite transatlantique des esclaves. Nous défendons l'idée que tant l'intoxication que la consommation de terre étaient des actes de résistance de la part d'esclaves qui ne contrôlaient leur propre corps que de façon limitée. Au dix-neuvième siècle, Bridgens n'est pas le seul propriétaire d'esclaves à assimiler ces attitudes rebelles à des maladies et des dépendances. Notre hypothèse est que les Américains et les Européens ont utilisé cette stratégie représentationnelle pour trouver une explication au fait de manger de la terre ainsi qu'aux tentatives d'échapper à l'esclavage : les concepts de maladie et de dépendance leur permettaient de renvoyer ces attitudes de résistance du côté de l'irrationnel plutôt que de les reconnaître comme des signes de connaissance et de contrôle de leur propre corps par les esclaves. La mise en exergue des lacunes, inconsistances, doutes et aveux d'ignorance qui caractérisent le texte de Bridgens ouvre la perspective et pousse les chercheurs à questionner ce que ses choix esthétiques révèlent sur sa vision biaisée de l'esclavage. La lecture critique des images et du texte met aussi en évidence les problèmes surgissant lorsque les représentations de l'esclavage sont appréhendées comme des récits historiques exacts.

La question qui subsiste est alors celle-ci : si les faits textuellement rapportés par Bridgens dans West India Scenery sont incorrects ou inexacts, quels éléments de sa représentation visuelle devraient-ils être considérés comme incorrects ou inexacts?
Tous droits réservés (C) UAAC-AAUC (University Art Association of Canada | Association d'art des universités du Canada), 2011
Ce document est protégé par la loi sur le droit d'auteur. L'utilisation des services d'Érudit (y compris la reproduction) est assujettie à sa politique d'utilisation que vous pouvez consulter en ligne.

https://apropos.erudit.org/fr/usagers/politique-dutilisation/ 


\title{
Representing Punishments for Dirt-Eating and Intoxication in Richard Bridgens's West India Scenery, with Illustrations of Negro Character (1836)
}

\author{
Julia Skelly, Concordia University
}

\section{Résumé}

Notre article se concentre sur l'étude de deux gravures de l'ouvrage West India Scenery dans lequel l'auteur, Richard Bridgens, a représenté des esclaves_-dont certains récemment affranchis_qui sont punis pour avoir mangé de la terre et s'être intoxiqués. Bridgens désigne la consommation de terre comme une dépendance et une maladie en même temps, sans se donner la peine d'expliquer pourquoi les esclaves buvaient au point de s'intoxiquer, ni pourquoi l'ivresse était considérée comme punissable dans le contexte de la traite transatlantique des esclaves. Nous défendons l'idée que tant l'intoxication que la consommation de terre étaient des actes de résistance de la part d'esclaves qui ne contrôlaient leur propre corps que de façon limitée. Au dix-neuvième siècle, Bridgens n'est pas le seul propriétaire d'esclaves à assimiler ces attitudes rebelles à des maladies et des dépendances. Notre hypothèse est que les Américains et les Européens ont utilisé cette stratégie représentationnelle pour trouver une explication au fait de manger de la terre ainsi qu'aux tentatives d'échapper à l'esclavage : les concepts de maladie et de dépendance leur permettaient de renvoyer ces attitudes de résistance du côté de l'irrationnel plutôt que de les reconnaître comme des signes de connaissance et de contrôle de leur propre corps par les esclaves. La mise en exergue des lacunes, inconsistances, doutes et aveux d'ignorance qui caractérisent le texte de Bridgens ouvre la perspective et pousse les chercheurs à questionner ce que ses choix esthétiques révèlent sur sa vision biaisée de l'esclavage. La lecture critique des images et du texte met aussi en évidence les problèmes surgissant lorsque les représentations de l'esclavage sont appréhendées comme des récits historiques exacts.

La question qui subsiste est alors celle-ci : si les faits textuellement rapportés par Bridgens dans West India Scenery sont incorrects ou inexacts, quels éléments de sa représentation visuelle devraient-ils être considérés comme incorrects ou inexacts?

White artists and black bodies ${ }^{1}$

$\mathrm{R}$ ichard Bridgens's West India Scenery, with Illustrations of Negro Character, the Process of Making Sugar, etc. from Sketches taken during a Voyage to, and Residence of Seven Years in, the Island of Trinidad was published in 1836, three years after slaves were legally emancipated in the British colonies of the Caribbean, although many slaves continued to be held in bondage under the euphemistic term "apprenticeship" until 1838.2 West India Scenery is comprised of twenty-seven lithographs that portray a range of subjects, including topographical views, Africans engaged in labour, and various forms of corporeal punishment. ${ }^{3}$ Bridgens (1785-1846) describes each image in a short accompanying text on the opposite page, and he signals his own contribution to the illustrations with the phrase "From nature and on stone by R. Bridgens," indicating that he drew the scenes in person and then on lithographic stone, before the series was completed and printed with the assistance of other artists.

Although art historians, including Kay Dian Kriz, have recently discussed West India Scenery in books concerned with slavery and visual culture, there has not been extensive scholarship focused on Bridgens. This article is intended to contribute to the growing literature on Bridgens as a graphic artist and to the study of visual culture and slavery more generally. ${ }^{4}$ Many details about Bridgens's life and career remain sketchy. AfroCaribbean scholar Judy Raymond attributes this in part to his lack of self-promotion, but also to errors in primary sources. For instance, although Bridgens did "important work" on the interior of Sir Walter Scott's home, Abbotsford House, the first few times Bridgens appears in Scott's letters his name is incorrectly recorded as "Mr Buggins." 5 Bridgens appears to have started his career as a furniture designer in Liverpool, but that venture was generally unsuccessful, as was his architectural practice in Birmingham. In 1826 he travelled to Trinidad with his family because his wife had inherited a share in a sugar plantation. Following his arrival in Trinidad, Bridgens became the Superintendent of Public Works and designed a new block of government buildings, the foundation stone of which was laid on 15 February $1844 .{ }^{6}$ Although he refers to a seven-year residence in Trinidad in the extended title of West India Scenery, Raymond has pointed out that Bridgens in fact lived in Trinidad for approximately twenty years, until his death in Port of Spain in November 1846.7

In this article I discuss two of Bridgens's illustrations from West India Scenery that represent the punishment of African individuals. As I will show, there is some ambiguity in the text about whether the images were intended to portray slaves or newly freed slaves. In an article that critically examines John Gabriel Stedman's Narrative of a Five Years Expedition against the Revolted Negroes of Surinam in Guiana on the Wild Coast of South America; from the Year 1772-1777, art historian Marcus Wood remarks that the depictions of punishment engraved for the book by William Blake, the well-known British artist, and Francesco Bartolozzi, an Italian painter, "raise tricky questions relating to the trans-historical nature of aesthetics, torture and the fetish." 8 Wood argues that the representations of the tortured or punished black body in Stedman's Narrative functioned as pornographic images for white viewers, because they objectify the slave body and eroticize slaves' pain. ${ }^{9}$ In what fol- 
lows, my discussion is quite different from Wood's, in part because I do not believe that Bridgens's representations of punishments are pornographic. Rather, I investigate two images that depict punishments for dirt-eating and drunkenness in order to argue that these behaviours were perceived as punishable because they were correctly identified as acts of resistance by some, but not all, slave owners. I also suggest that there is a failure in Bridgens's text to properly account for both dirt-eating and intoxication within the context of transatlantic slavery. I analyze Bridgens's illustrations alongside his text to reveal fissures in his discussion that unveil an inability to grasp the meanings of slaves' acts of resistance.

In Slavery, Sugar, and the Culture of Refinement: Picturing the British West Indies, 1700-1840, Kriz examines images such as the prints in West India Scenery in order to "disturb the currents of much modern text-driven scholarship by showing that art was central to the formation of [the] 'West-Indian-ized' racial category used primarily to designate sub-Saharan Africans and their descendants." $10 \mathrm{I}$ am also concerned with highlighting the importance of visual culture in accessing the history (or histories) of slavery and abolition. However, my methodology is informed by a desire to approach word and image together in order to illuminate how Bridgens employed various representational and textual strategies to make slave punishment both palatable and comprehensible to a white audience. I argue that he incorrectly identified dirt-eating as an addiction and a disease, a fact that scholars writing about Bridgens have not previously noted. ${ }^{11}$ By being attentive to the gaps and failures in the textual component of West India Scenery, I believe that new light may be shed on the illustrations themselves, as well as on representations of slave punishment by other nineteenthcentury artists.

The images that I examine at length are Bed-Stocks for Intoxication (fig. 1) and Negro Heads, with Punishments for Intoxication and Dirt-eating (fig. 2). The name "A. Ducôte" appears under the first image, while "Day and Haghe" is inscribed under the latter, identifying them as the artists who produced the lithographs from Bridgens's drawings. Alfred Ducôte, William Day, and Louis Haghe were all born in Europe. ${ }^{12}$ Therefore, like Stedman's Narrative, West India Scenery contains representations of suffering black bodies produced by European artists who were white and male. Furthermore, we can assume that the illustrated text was intended for a white British audience. These points are significant, for it is apparent that Bridgens attempted to produce both images and text that his white readers would find educational but not overly distressing. His book was not intended for an abolitionist audience, and his primary objective was likely to sell as many copies of the volume as possible. Even while representing punished and tortured bodies, Bridgens did not include bloody wounds in his illustrations, nor did he depict Africans in obvious physical or emotional agony. These omissions were likely based on a desire to circumvent the painful reality of slavery.

The top two figures in Negro Heads depict the same man in profile on the left and facing the viewer on the right. This representational strategy was common in ethnographic images produced by white European artists in the early nineteenth century that were intended to illustrate racial difference. ${ }^{13}$ Raymond believes that Bridgens may have represented his own slaves (or newly freed slaves), meaning that these depictions might in fact be portraits. ${ }^{14}$ However, in the absence of definite names or documentation confirming that the illustrations represent actual individuals, it is perhaps safer to describe the images as ethnographic types, although further research in Bridgens's archives in Trinidad may unearth evidence that his illustrations for West India Scenery were indeed portraits. In the middle row on the left, a female figure wears a white textile tied elaborately around her head. She is also depicted in profile, but is shown in a three-quarter turn away from the viewer, so we see even less of her face than the man shown in profile above her. The figure beside her is portrayed facing the viewer. Of the men in this illustration, Bridgens writes, "We have here representations of two of the various modes of tattooing in use among the native tribes of the West coast of Africa." 15 Bridgens also remarks that the woman's headwrap is "the usual head dress of the Negress." 16

Two different forms of punishment are represented at the bottom of the Negro Heads lithograph. The figure on the left is rendered androgynous by the metal mask placed over his or her mouth as punishment, we are told, for dirt-eating, and facing this figure is a woman wearing a metal collar. According to Bridgens, the collar was used specifically to punish female slaves for drunkenness, an argument I challenge later in this article. For now, I wish to make two points about Negro Heads. First, in describing the figures as ethnographic types, I am alluding to the tradition of white artists depicting Africans with stereotypical physiognomies, which functioned to degrade the black person represented because of connotations associated with those particular physiognomies within the contexts of ethnography and scientific racism. ${ }^{17}$ Graphic art depicting people of African descent proliferated in the eighteenth and nineteenth centuries. Caricatures of black men and women with exaggerated and grotesque facial features were particularly popular in Britain, and graphic representations produced under the auspices of the natural sciences were not exempt from stereotypes related to physiognomies and racial difference. Albert Boime has observed, "As an agent of ideological practice, visual expression often participates in the overreaction (those in power exaggerating the threat of those who are powerless) and thus discloses the fragile character of the very system it seeks to reinforce." 18 


\section{RACAR XXXVI | Number 2 | 2011}

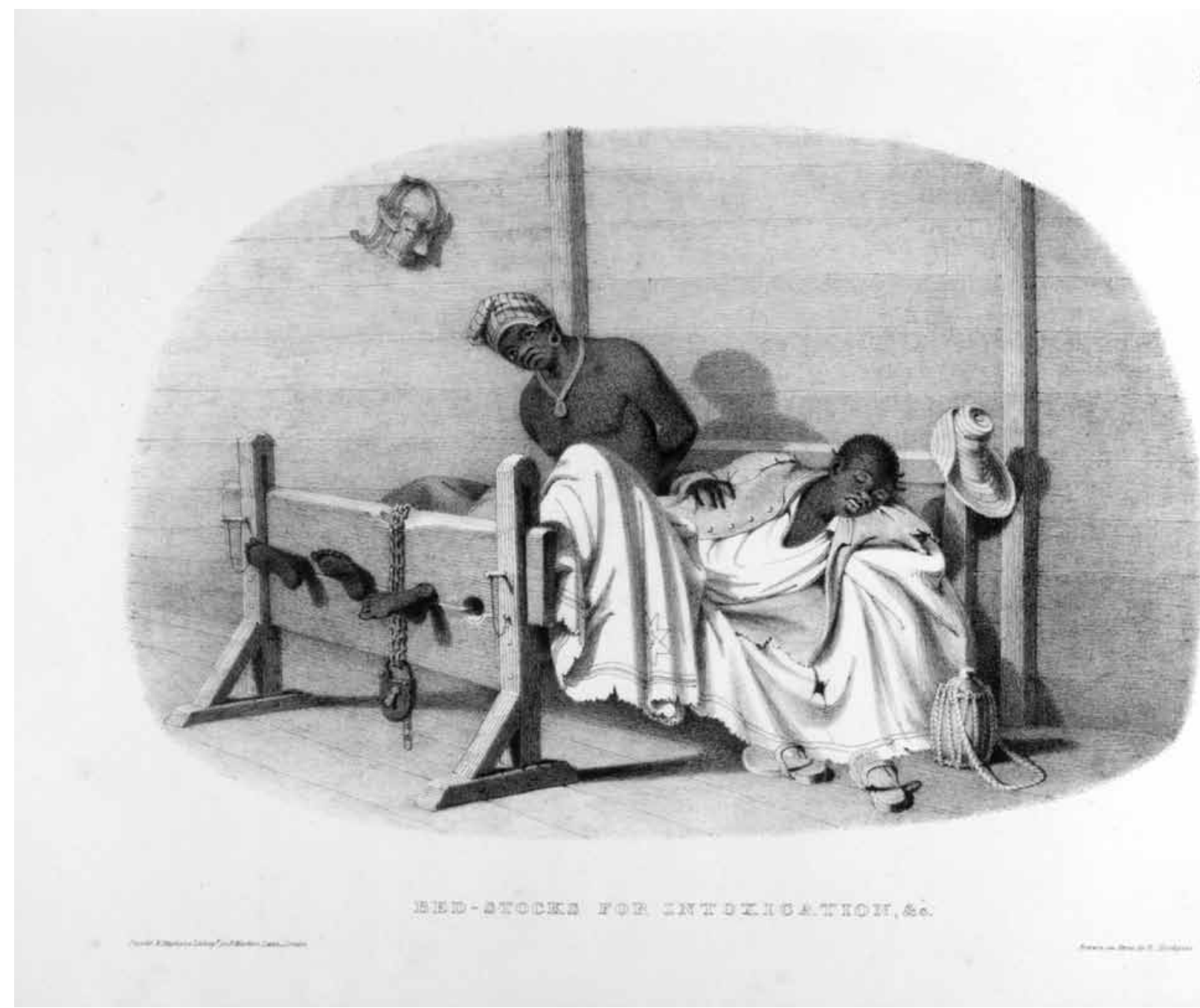

Figure I. Richard Bridgens and A. Ducôte, Bed-Stocks for Intoxication, from West India Scenery, with Illustrations of Negro Character, the Process of Making Sugar, etc. from Sketches taken during a Voyage to, and Residence of Seven Years in, the Island of Trinidad, I836. Lithograph, Yale Center for British Art, New Haven, Conn. (Photo: courtesy the Yale Center for British Art).

This statement is particularly relevant for the visual culture of slavery, as there was constant anxiety among white slaveholders about slave uprisings, and representations of slaves by white artists must be considered in light of this fact.

My second point is related to the strange juxtaposition occurring in Negro Heads. Tattoos, a headwrap, and punishments: Which of these is not like the others? The vaguely disturbing effect of the lithograph is caused by Bridgens's decision to represent aspects of African culture alongside a horrific part of slavery without clarifying his reasons for including them on the same page. Thus, I would argue, Bridgens naturalizes the punishment of slaves, and locates it as a necessary and justifiable part of plantation culture. Indeed, Bridgens does not critique institutional- ized punishment within the context of slavery, but rather represents it as a normal part of life in Trinidad. As noted previously, Bridgens's brief descriptions of the punishments expose a lack of comprehension regarding slaves' acts of resistance, which is fundamentally dependent on a failure to envision the possibility of slaves choosing self-destructive acts as forms of protest. This was common among British and American slave owners, as my conclusion will show.

It is not insignificant that both drinking alcohol to the point of drunkenness and eating dirt are acts of consumption. In the next section I address the implications of consumption and resistance within the context of plantation slavery, and I argue that slaves sometimes engaged in acts of consumption in 


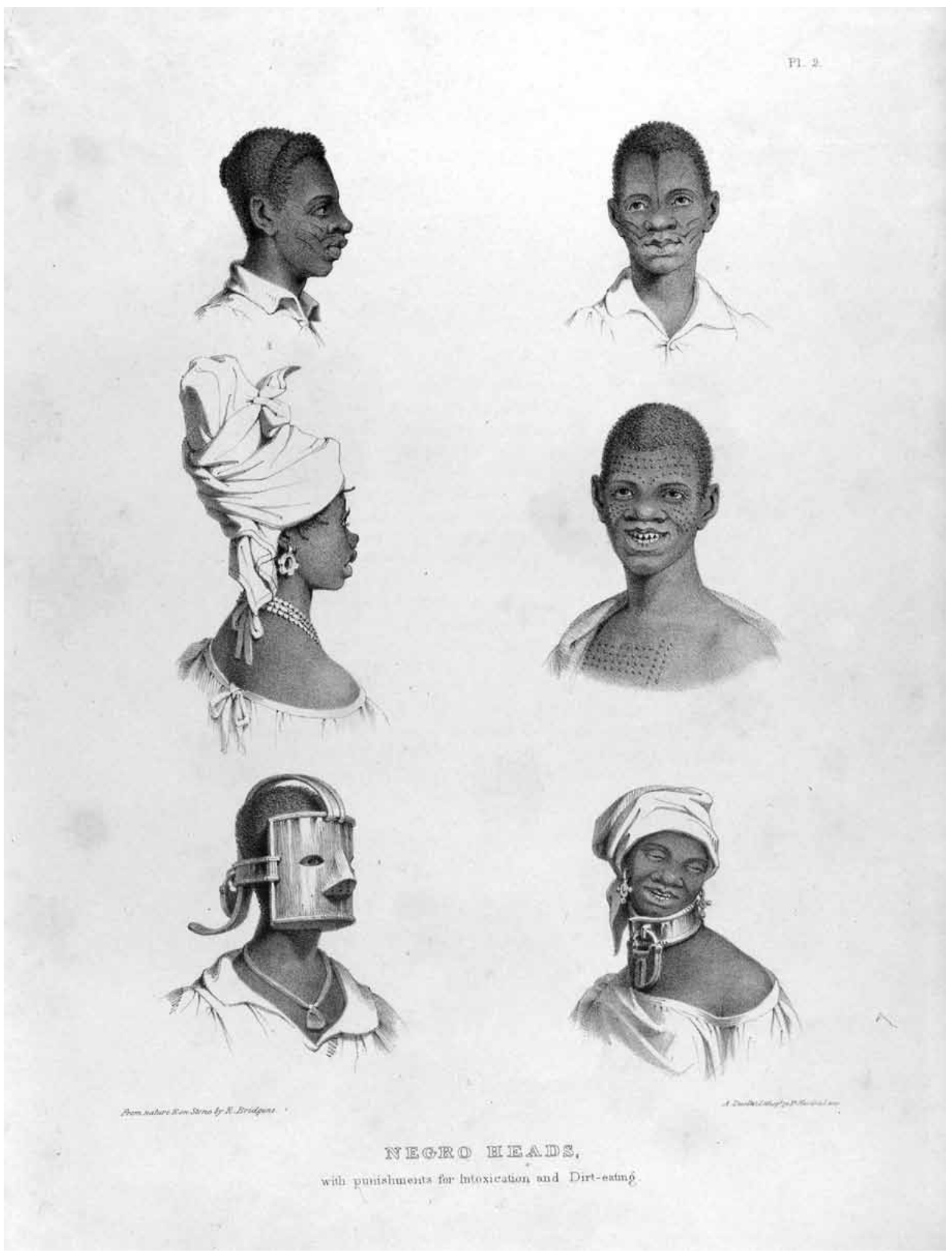

Figure 2. Richard Bridgens, Day and Haghe, Negro Heads, with Punishments for Intoxication and Dirt-eating, from West India Scenery, with Illustrations of Negro Character, the Process of Making Sugar, etc. from Sketches taken during a Voyage to, and Residence of Seven Years in, the Island of Trinidad, 1836. Lithograph, Yale Center for British Art, Paul Mellon Collection, New Haven, Conn. (Photo: courtesy the Yale Center for British Art). 
order to exert what control they could over their own bodies. Further to this, I show how discourses of disease and addiction informed white slave owners' perceptions of slaves' acts of resistance. Although Bridgens's text was published shortly after emancipation, I discuss his representations of punishment in relation to slavery. In Slavery, Sugar, and the Culture of Refinement, Kriz comments that West India Scenery is a "story of newly freed black slaves in Trinidad," and suggests that the bed-stocks were one of the "newly sanctioned forms of punishment" created to control the emancipated slaves. ${ }^{19}$ She makes this statement based on Bridgens's own comment that the punishments he represents "are those now authorized to be inflicted."20 I propose, however, that while the bed-stocks, collar, and mask may have been newly (or re-)authorized for a post-emancipation context, they were not new in 1836 but had been used to punish slaves for many years in various geographical locations. ${ }^{21}$ Therefore, in my discussion of punishments for intoxication and dirt-eating, I contextualize them in relation to slaves and slavery, while also acknowledging that they may well have been used to punish newly freed slaves. I propose that these images be considered part of the vast visual culture of slavery that scholars such as Kriz, Charmaine Nelson, Michael Hatt, and Marcus Wood, among others, have critically examined. ${ }^{22}$

\section{Contextualizing Consumption as Resistance}

Both consumption and resistance in the nineteenth century have garnered much scholarly attention, and these issues have also been discussed specifically in relation to slavery. Charlotte Sussman has examined how white British citizens employed nonconsumption as a political strategy in order to condemn slavery, ${ }^{23}$ and Stephanie Camp discusses slaves' illicit parties that involved consumption of food and alcohol. 24 The present article will add to this field of inquiry by focusing on the ways that slaves embraced two specific forms of consumption: namely, dirt-eating, and drinking alcohol to the point of intoxication. It is because of Bridgens's representations of punishment that I began to examine these acts of consumption in relation to each other, thus pointing to the importance of visual culture in the study of slavery. Kriz briefly discusses Bed-Stocks for Intoxication in Slavery, Sugar, and the Culture of Refinement, 25 while Jeremy MacClancy alludes to the figure with the mask represented in Negro Heads in his short essay on geophagia in literature and art. 26 I build on these studies by further analyzing and connecting Bridgens's two illustrations and by drawing on nineteenth-century sources in order to show how acts of consumption were both perceived and embraced as acts of resistance.

In Consuming Subjects: Women, Shopping and Business in the Eighteenth Century, Elizabeth Kowaleski-Wallace remarks upon the dual meanings of "consume," observing, "To consume is either to take in what one needs to survive or to waste away in a fit of disease." 27 My discussion complicates KowaleskiWallace's definitions of "consume," as neither dirt nor alcohol are necessary for survival; historical evidence indicates that slaves consumed both to the detriment of their bodies. In addition, the acts of consuming dirt and alcohol were both identified as diseases by various individuals in the nineteenth century. I am specifically concerned with the consumption of substances ingested by the body because of the pivotal position that the body occupied within the context of transatlantic slavery. As Camp has noted, "For bondswomen, even more than for enslaved men, intimate entities, such as the body and the home, were instruments of both domination and resistance." 28 I frequently return to the question of choice, as this was intensely significant for slave women, not only because of the everyday reality of enforced, unpaid labour, but also because of the rampant sexual exploitation that took place. ${ }^{29}$ If female slaves could not always choose when white men entered their bodies, they could, sometimes, choose when to consume (or not consume) substances including alcohol and dirt.

Slaves' consumption was not a simple matter. While slaves sometimes used consumption as a strategy of resistance, it could also be used as a strategy of control by slaveholders, and the power struggle revolving around slaves' alcohol consumption, for instance, was complex. One reason that drunkenness was regarded as punishable within the context of slavery was that it had negative economic consequences. Camp has shown how slave owners fretted over lost labour caused by slaves' hangovers and their inability to work efficiently the day after drinking to the point of intoxication. ${ }^{30}$ Yet Susan Zieger has observed that slaveholders were known to encourage drunkenness in slaves in order to induce physical illness. She remarks, "Since masters attempted to stage slaves' nausea as the outcome of their drunken frivolity, this sickness certainly counts as a form of intimate, institutional violence." 31

An additional complicating factor was the question of who had the power to choose not to consume as a political strategy. Sussman examines the "abstention movements" in which some white abolitionists participated. The choice to not consume colonial products such as "sugar, tea, chocolate, [and] coffee" was predicated on the belief that, in not consuming these products, individuals were staging protests against slavery, as it was slave labour that had produced these items. ${ }^{32}$ Sussman does not discuss alcohol and its place in this matrix of production and nonconsumption, although as a product of slave labour it was certainly part of it. Addiction scholar David Courtwright has stated that rum was a "key commodity in the slave trade that provided the labour which produced the sugarcane in the first place."33

According to Sussman, for white English citizens, nonconsumption was a political strategy that was predicated on their 
freedom to choose what they would or would not consume. As she points out, "Only as consumers, a category of economic agent given new preeminence in the free-market capitalism of the later eighteenth century, could these campaigners [for abolition] proclaim their political power." 34 For African slaves, who did not have the same relationship with the objects and substances that they produced, consumption might have suggested itself as a more powerful statement. It would be inaccurate, however, to conclude that slaves never used nonconsumption as a strategy of resistance. Abolitionist Richard Hillier wrote in 1791 ,

[The slave] cannot think why...the wretches who have laden him with chains are desirous that he should eat; he cannot account for their brutal kindness; he concludes that they mean to fatten him, in order to feast upon him at a convenient season. He resolves to circumvent their designs; he refuses food: he is whipt to make him eat; but the indignant firmness of his mind is not to be subdued by the lash. The speculum oris is resorted to; a broken tooth gives an opportunity for its introduction; his mouth is forced open, rice is crammed down his throat, and he is compelled to live. 35

Unlike the white Europeans who, because of their privileged position as consumers, could choose not to consume particular products, a slave who chose not to consume as a form of resistance could be punished and forced to consume so that the slave's owner would not lose a labouring body.

Although I do not wish to conflate slaves' suffering with that of any other group, I believe it is worth noting that white suffragettes who engaged in hunger strikes in the late nineteenth century also experienced force-feeding at the hands of male authority figures. Feminist art historian Rosemary Betterton has called force-feeding "a form of psychological torture which is also a physical violation of the female body," and she argues that the "forcible penetration of the hunger striker's body by a feeding tube inserted into her throat through a steel gage which prised her jaws apart was directly analogous to the instrumental rape by the steel speculum of women believed to be engaged in prostitution under the nineteenth-century Contagious Diseases Acts." 36 Here again we see how the forced consumption of food has historically intersected with the sexual violation of women's bodies.

I argue that both dirt-eating and drunkenness were punished because they were perceived as forms of resistance. This may seem obvious, but it appears that it was not obvious to Bridgens. His illustrations and text reveal gaps, inconsistencies, doubts, and admitted ignorance. I contend that West India Scenery is emblematic of an interpretative strategy that positioned acts of resistance as addictions and diseases within the context of slavery. The illumination of Bridgens's failure to understand the realities of slaves' lived experience is highly relevant for scholarship on his images, as it opens a space for scholars to question what his aesthetic choices may reveal about this white artist's skewed vision of slavery. It also points up the problems associated with viewing representations of slavery as accurate historical records. The question is then: If Bridgens's textual accounts in West India Scenery are incorrect or inaccurate, what might be incorrect or inaccurate in his visual representations?

\section{Representing Punishment I: Bed-Stocks for Intoxication}

Bed-Stocks for Intoxication (fig. 1) portrays two black men being punished, and it is implied, both in the title and the accompanying text, that their offence is drunkenness. In his description of the image Bridgens writes,

This is one of a series of plates, in which it is proposed to
exhibit the various kinds of stock directed by Government
to be used in the Crown Colonies before the Abolition Act
was passed. It may be seen, from the care taken for the ease
of the prisoner, that no punishment is attempted in the Bed-
Stock beyond confinement of the person. They are generally
placed in some of the out-houses belonging to the estate,
where the offender may be denied the society and encour-
agement of his friends or accomplices. The Bed-Stocks are
usually, indeed, employed in cases of drunkenness; when
the individual is callous to the shame of exposure....A tin
mask, such as is put on the heads of Negroes addicted to
the unaccountable propensity of dirt-eating, is seen hanging
against the wall. 37

First, it is crucial to note that, according to Bridgens, he is representing a kind of "stock directed by Government to be used in the Crown Colonies before the Abolition Act was passed." The implication is, then, that the stocks were legally used on slaves in Crown Colonies before the Abolition Act of 1833 was passed, but that after the Act was passed the stocks were no longer a legitimate form of punishment. However, Kriz has argued that Bridgens was portraying "newly sanctioned forms of punishment" created to control the newly freed slaves. ${ }^{38}$ These punishments may have been newly (re-)sanctioned, but they were not new, and it is unlikely that slave owners would abruptly cease to employ their accustomed forms of punishment the moment the Abolition Act was passed, particularly because the so-called apprenticeship of slaves continued until at least 1838 . It is therefore unclear whether Bridgens is representing scenes that he observed prior to 1833 or after the Act was passed.

Bridgens's descriptions of both the punishments and the behaviours that were punished reveal that he failed to fully com- 
prehend some of the things he witnessed in Trinidad. I wish to underscore Bridgens's reference to the tin mask hanging on the wall, which, he states, is placed on the heads of slaves "addicted to the unaccountable propensity of dirt-eating." Like slaves' alcohol consumption, the history of their dirt-eating is a narrative complicated by various conflicting interpretations of the act. Wood has identified dirt-eating as one of the ways that slaves attempted to commit suicide. ${ }^{39}$ However, Jerome Handler and Annis Steiner have suggested that slaves' consumption of dirt was not solely based on a desire for death. In their discussion of French writer and artist Jacques Etienne Victor Arago's representation of a Brazilian slave wearing a metal plate over his mouth, published in the 1839 edition of his Promenade Autour $d u$ Monde, they show how slaveholders' perceptions of slaves' dirt-eating influenced how European travellers wrote about the act. Arago reported in Promenade that slaves were punished by wearing tin masks "because their misery caused them to eat earth to end their lives." 40 According to Handler and Steiner, Arago made this observation because "he was told" that slaves ate dirt in order to commit suicide so as to escape punishment in the form of whipping. They state, "This was a common reason given by slaveholders throughout the New World for 'dirt eating' or geophagy, a behavior that, in fact, was prompted by nutritional deficiencies." 41 There is, then, something of a "chicken and the egg" dilemma about slaves' dirt-eating. While slaves may well have begun eating dirt in desperate attempts to nourish their bodies, the act sometimes resulted in death, thereby becoming recognizable to slaves as a potential way to commit suicide. It simultaneously led slaveholders to perceive dirt-eating as a form of resistance that merited punishment. I locate slaves' dirt-eating as an act of resistance predicated on a desire to exert control over their bodies, even though the end result of this particular strategy was sometimes death.

Bridgens's curious use of the term "addicted" to refer to the act of dirt-eating points to three interconnecting assumptions: first, that eating dirt was a harmful activity; second, that slaves knew that it was a harmful activity; and third, that despite knowing that it was harmful, and not wanting to do it, they did it anyway. It is important to illuminate the distinction between choice and the loss of choice that characterizes addiction. The word "addicted" as it was used in the eighteenth century was a legal term that referred to acknowledged servitude, later evolving to signify that the addicted person was enslaved to something, thus implying that there was a lack of choice and agency in relation to the activity in question. Bridgens's use of this word in the context of slavery had various implications, but one was that slaves were positioned as doubly enslaved, and newly freed slaves were framed as still enslaved (albeit to a behaviour rather than to a person). If slaves were, hypothetically speaking, addicted to eating dirt, it would mean that although they knew that eating dirt was harmful to them, and despite having the desire to not eat dirt, they did it anyway. I propose, in contrast, that slaves who consumed dirt had specific objectives (whether the objective was to nourish the body or, paradoxically, to commit suicide), indicating cognition, conscious choice, and power over body and decision-making faculties, which negates Bridgens's identification of dirt-eating as an addiction. Although suicide is ultimately the destruction of self, for slaves it could be a powerful, albeit tragic, statement of ownership over their own bodies. 42

Wood has observed, "If the slave body was property, the slave personality was not, and the majority of torture inflicted on slaves grew out of the desire to break down the personality of the subject/victim, to generate and then enforce a consciousness of disempowerment and anti-personality." 43 The physical punishments (or tortures) invented and adapted to punish slaves for drunkenness very deliberately controlled the body so as to exercise control over the mind as well. Bridgens's remark accompanying Bed-Stocks for Intoxication, quoted earlier, that "from the care taken for the ease of the prisoner, [it is apparent] that no punishment is attempted in the Bed-Stock beyond confinement of the person" seems to suggest that there is no psychological component to the punishment. However, the lack of mobility would have had the consequence of making basic bodily functions an additional source of physical discomfort, and there would have been the likelihood of having to sit in one's own, or another person's, bodily fluids. This, of course, would have had both a physical and psychological impact on the offender. ${ }^{44}$ Bridgens also notes that the prisoner is "denied the society and encouragement of his friends or accomplices." The enforced lack of human contact (although the illustration shows two figures in the bed-stocks) would have inevitably had mental and emotional effects. It would not have been the length of confinement so much as the removal of choice, and of course the physical discomfort that Bridgens shows quite clearly on the faces of the two men, despite the fact that he refers to the "care taken for the ease of the prisoner." The fact that the man on the right has his eyes closed and a contorted expression on his face heightens the ambiguity. Is he sleeping? This would support Bridgens's claim that care was taken for the physical comfort of the slave, as the bed - though a device of punishment-is represented as comfortable enough to sleep in. Or are the man's eyes closed in agony and distress? There are multiple disconnects between the text and the image, which may indicate Bridgens's (conscious or unconscious) ambivalence about the scenes he witnessed while living in Trinidad.

According to Kriz, after emancipation, illustrations concerned with slavery "could not maintain credibility without addressing in some way the violence associated with slavery, while maintaining the moral superiority of the local plantoc- 
racy. One solution was to resort to an empirical or ethnographic representation in order to present the violence directed against newly freed slaves as necessary restraint." 45 Although Bridgens represents and describes modes of punishment, he does not appear to condemn the practice. MacClancy has called Bridgens an "apologist of slavery." 46 Certainly he does not come across as a fierce abolitionist, and we must remember that he was a slave owner. His text could be described as "emancipation propaganda," a phrase used in Wood's recent book The Horrible Gift of Freedom: Atlantic Slavery and the Representation of Emancipation. 47 If the subjects represented in Bridgens's text are indeed newly freed slaves, West India Scenery functions as emancipation propaganda in the sense that it ostensibly represents the changes brought about by abolition of the British slave trade, while apparently condoning the continued corporeal punishment of African men and women who were no longer, strictly speaking, slaves. "At the core of the [emancipation] myth," Wood writes, "is one enormous idea, the idea that a government that has presided over the development and maintenance of colonial slavery can at a certain point decide to abolish and to give freedom to the slave." 48 Bridgens's representations of punishments signify prolonged lack of freedom, and thereby put the lie to emancipation.

Bridgens remarks that bed-stocks are "employed in cases of drunkenness, when the individual is callous to the shame of exposure." Shame was an ideological tool employed in Britain in the nineteenth century to control excessive alcohol consumption. It was particularly effective, if not in eliminating white women's drinking, then certainly in motivating their attempts to hide their drinking. ${ }^{49}$ Concerns about white women's alcohol consumption coincided and intersected with anxieties about their consumption in general.50 Significantly, however, shame was often regarded as an exclusively white affect. According to racist ideologies, non-white individuals were incapable of shame, a belief that was promulgated by commentators on the difference between alcohol consumption by Europeans and Africans. British temperance writer Ralph Grindrod, for example, remarked in 1843, "The untutored savage, restrained by no principles of shame or propriety, abandons himself to insatiated and unbounded excess." 51 According to Grindrod, "savages" drank to excess because they were not restrained by the principles of shame or propriety, which were, as we know, principles by which many white British citizens believed they should live and die. But Grindrod adds an important qualification to the above statement when he observes,

The drinking practices, however, of civilized nations, in some respect, differ materially from those of the unpolished and unguarded savage. The object of an intemperate member of the former class, is not how he can attain the readiest method of intoxication, but how he can attain the highest degree of animal and pleasurable excitement, without the exhibition of any visible signs of what is commonly denominated intemperance. 52

Grindrod's point, of course, is not that non-Western individuals drink more excessively than Western individuals, but rather, that because of the principles of shame and propriety, white individuals attempt to hide the "visible signs" of intemperance. 53 Non-Western drinkers, on the other hand, were "callous to the shame of exposure."

In some nineteenth-century literature in which abolition concerns intersected with those related to temperance, writers commented on how Europeans had introduced alcohol to Africa and were therefore responsible for African drunkenness. For instance, Grindrod writes,

\footnotetext{
The history of other countries shows that intemperance is not peculiar to Great Britain and Ireland. The inhabitants of many countries in a semi-barbarian state, previous to their connexion with the Christian world, had discovered the art of producing intoxicating substances, in various ways. Others learned the trait of inebriation from European nations, who at the same time supplied them with these pernicious articles for consumption. The inhabitants of Ashantee, Congo, and other African nations, are described by travelers as indulging freely in the use of strong drink, for which they are doubtless more or less indebted to their intercourse with European nations; and, especially to their accursed trade in human flesh. 54
}

These texts, sympathetic though they were to the plight of slaves, often framed Africans as savages who knew no better than to consume excessive amounts of the alcohol that white Europeans had brought amongst them, and thus they needed to be saved from both slavery and drunkenness by other white Europeans. Grindrod observes, "The heathens were much addicted to intemperance at the time when the Gospel was introduced to their notice," thus suggesting that with the Gospel came temperance for the poor "heathens" who had become addicted through "simple ignorance." 55

The question of whether alcohol consumption by male and female slaves was perceived differently based on gender within slave communities is a question that demands further research. Surely the pleasure and intoxicating effects caused by alcohol would have been appealing to both male and female slaves. Camp suggests that male slaves were more likely to consume alcohol on American plantations, 56 but later she remarks that some slave women did drink alcohol.57 This is supported by Bridgens's observation that metal collars were used to punish female slaves for drunkenness. As noted earlier, Camp examines 
clandestine slave parties, which were an important facet of slave life in terms of both resistance and alcohol. There are several aspects of these parties that are relevant for my discussion. First, they involved such sensual pleasures as drinking alcohol, eating, dancing, and dressing up. Camp emphasizes the fact that the slave body was a site of both pleasure and resistance, and she remarks, "Just as exploitation, containment, and punishment of the body were politically loaded acts, so, too, was slaves' enjoyment of their bodies." 58 Central to the illicit parties was slaves' power of choice to engage in sensual activities that often included acts of consumption.

The second thing to note about these parties was the fact that slaves engaged in theft in order to obtain food and drink for the festivities. Camp notes that female slaves were often responsible for procuring alcohol for the parties, and if caught, they were punished. 59 This, then, is another instance of slaves risking punishment in order to consume alcohol, and of being punished for acts related to alcohol, even if the slave did not drink to the point of drunkenness. The risks were apparently regarded as worthwhile, however, a fact that is explained in part by slave Austin Steward's observation that at self-organized slave parties "suffering and toil was forgotten, and they all seemed with one accord to give themselves up to the intoxication of pleasurable amusement."60 Again, choice and agency are central here. As Pamela Gilbert has suggested, "Desire is movement."61 Slaves' desire for pleasure and control over their own bodies sometimes involved transgressing plantation boundaries in order to attend illicit parties, and fulfilling their desire often involved the risk of punishment.

What was it about slaves' (or newly freed slaves') drunkenness that plantation owners deemed punishable? Bridgens never elucidates this point for his readers. Was it that drunkenness interfered with labour? According to Camp, this was certainly one reason. ${ }^{62}$ I believe another reason was that drunkenness signified the act of seeking either (mental) escape or pleasure, thus once again pointing to a slave's power over his or her own body. In Camp's discussion of female slaves and resistance on American plantations, she describes everyday forms of resistance as "those small acts with sometimes outsize consequences."63 She identifies theft, foot dragging, short-term flight (that is, running away but returning not long after), and feigning illness as instances of everyday resistance. With this in mind it is helpful to turn to a passage in John Gabriel Stedman's Narrative of a Five Years Expedition because it illustrates further how slaves' drunkenness was perceived by at least some slave owners. As Camp reminds us, slaveholders' responses (including punishment) to slaves' actions are significant because they reveal which behaviours were regarded as potentially threatening to the stability of plantation life. ${ }^{64}$ Stedman describes an overseer who reported to the plantation owner every morning with news of the previous day.
The overseer recounted which slaves "deserted, died, fell sick, recovered, were bought or born," and "above all things, which of them neglected their work, affected sickness, or had been drunk or absent." The author also notes that "the prisoners are generally present, being secured by the negro-drivers, and instantly tied up to the beams of the piazza, or a tree, without so much as being heard in their own defense." 65 This passage indicates that drunkenness was at least sometimes linked with affected sickness and absence, both acts that Camp identifies as everyday forms of resistance, thus suggesting that the slaveholder described by Stedman perceived slaves' drunkenness as resistance. That these acts were reported "above all things," reveals that they were regarded as threatening to the overall functioning of the plantation, and therefore demanded punishment.

Slaves' desire to escape, whether through intoxication or physical movement through space, exposed the great lie upon which slavery was founded. Many white Europeans believed, or purported to believe, that slavery was a benevolent part of the "white man's burden" of raising non-white peoples up from their uncivilized depths. ${ }^{66}$ Surely the deep-rootedness of this ideology explains why acts of resistance were often regarded as addictions and diseases, which not only served to frame the acts as irrational, but also justified further white control.

\section{Representing Punishment II: Masks and Collars}

The bed-stocks effectively immobilized the slave, psychologically underscoring the fact that the slaveholder owned his or her body, and that escape or absence, in whatever form, was prohibited. Other forms of punishment sent different psychological messages to slaves, no less destructive, but focusing on other aspects of identity and the body. In Bridgens's engraving Negro Heads, with Punishments for Intoxication and Dirt-eating (fig. 2) two forms of punishment are represented. On the left, a black individual wears a tin mask similar to the one hanging on the wall in Bed-Stocks for Intoxication, which serves to link the two illustrations. The mask has a curved metal plate that covers the entire face, and pieces of metal run from the top and sides to the back of the head where the mask is locked into place. A stylized nose projects from the front and there are tiny slits for viewing, but vision would have been obscured. On the right, a woman wears a metal collar with a large padlock hanging from the front. While the figure on the right is clearly female, the figure on the left is rendered androgynous by the mask, although the person is likely meant to be a man. This individual has the close-cropped hair of the man on the right in the bed-stocks image, and wears the same necklace as the man on the left in that illustration. Furthermore, this figure wears the same shirt as the tattooed man depicted at the top of Negro Heads, and it is possible that Bridgens based all of these drawings on the same 
person. In his discussion of an 1805 image that represents an African slave wearing a metal mask, Wood points to the androgyny of the figure as a noteworthy feature of this punishment:

The fragments of the face, the chest cropped at bust length, could belong to either sex. This enforced androgyny is doubly significant in view of the fact that the slave mask was one of the many punishment devices devised in the West for the punishment of women and then re-adapted for use on both sexes in the colonial slave plantations. ${ }^{67}$

The androgyny of the figure wearing the mask in Bridgens's illustration functions to desexualize and dehumanize, just as the actual object did in lived experience.

Bridgens observes that the metal mask was used to punish dirt-eating (as he also does in his description of the bed-stocks image), and appears to suggest that the collar was used exclusively for the punishment of women's intoxication:

The tin collar is a punishment for drunkenness in females. The mask is used as a punishment and preventative of the practice of dirt-eating, a disease peculiar to the Negro, and for which no satisfactory cause has been hitherto assigned. 68

It is significant to note that Bridgens identifies the collar as a form of punishment reserved for female drunkenness, as this is one of the errors he made in his text. Wood has demonstrated that male slaves were also forced to wear metal collars as punishment, usually for attempting to run away. ${ }^{69}$ It appears that Bridgens's knowledge was either limited or incorrect, which is substantiated when he remarks that "no satisfactory cause has been hitherto assigned" to dirt-eating, revealing his ignorance about this particular act of consumption and resistance. Bridgens frames dirt-eating as a "disease," and thereby avoids the need to explain why slaves would choose to ingest dirt. In nineteenth-century Britain, disease was widely viewed as an uncontrollable and malignant force, and it was therefore a pervading source of anxiety. Bridgens likely meant that dirt-eating was a disease of the mind, rather than of the body; nonetheless, the word "disease" was heavily loaded during this period with implications about morality and social disorder, and its use in Bridgens's text may have functioned discursively to heighten white readers' already-present anxieties about newly freed slaves.

Bridgens also seems to suggest that the metal mask was used only for punishing dirt-eating and not for drunkenness. I would argue that it is highly unlikely that the mask was never used to punish intoxication, simply because of the obvious orality of drinking and the concealment of the mouth that the mask enacts. The mask, unlike the collar, effectively controlled slaves' consumption, as well as their communication, and was therefore probably used for the punishment of both intoxication and dirt-eating. Indeed, Thomas Ewbank, the author of Life in Brazil (1856), produced for that text a visual representation of a female slave wearing a metal mask similar to the one portrayed in Negro Heads. ${ }^{70}$ He comments that the mask was "the reputed ordinary punishment and preventative of drunkenness....[It] is to hinder him or her [the slave] from conveying the liquor to the mouth. ${ }^{71}$ According to Ewbank, then, the mask was used on both male and female slaves to punish intoxication. As I have argued, because of the oral nature of consumption, the mask, which covered the mouth and made consumption impossible, was a logical (if I can use that term in this context) punishment for both intoxication and dirt-eating. Handler and Steiner discuss an article on Brazilian slavery published in Le Magasin Pittoresque in 1846 that made a connection between the mask, alcohol, and dirt. The article, which was illustrated by yet another representation of a male slave wearing a metal mask, ${ }^{72}$ this one by M. Bellel, describes how, because of their despondency due to terrible treatment, slaves attempted to "poison themselves" by consuming excessive amounts of alcohol or by eating dirt, and slaveholders forced slaves to wear the metal masks in order to prevent the consumption of these substances. ${ }^{73} \mathrm{Un}$ like Bridgens then, the anonymous author of the 1846 article identifies the mask as a form of punishment for both alcohol consumption and dirt-eating.

The collar punished by way of its weight and its resulting discomfort, and perhaps it was used more often on women than on men because it was thought that it would be more painful on women's bodies than on men's. However, it is important to note that it was unusual for slave owners to distribute different punishments based solely on gender. Marietta Morrissey observes, "Slave owners generally treated bondwomen like bondmen, subject to the same punishments.... There appears to be little difference in the severity with which men and women were punished, although men may have been brutalized more frequently." 74 Sometimes collars also had bells on them, which were intended to keep slaves from running away. ${ }^{75}$ The weight of the collars was also meant to have this function. Due to the fierce heat of the Caribbean, the metal of both the mask and the collar may have had the additional effect of burning the skin, resulting in scarring and a permanent mark on the body. ${ }^{76}$ This consequence is particularly resonant because of the practice of branding that was a common atrocity enacted by slave owners.

In Bridgens's illustration the collar looks suspiciously like an over-sized necklace, with the padlock as a sort of pendant. The rims along the top and bottom of the collar, the sheen of the metal, and the curve of the padlock where it slides through the collar all work to aestheticize the object, complementing the earrings that the woman wears and mirroring the actual necklace worn by the androgynous figure facing her. The aestheticization of a device of torture effectively empties it of its weight, 
both literally and symbolically, thus diminishing the possibility of empathetic viewing by the white nineteenth-century reader. ${ }^{7}$ The visuality of this punishment turned the slave body into a spectacle that was founded on both pain (the slave's) and power (the slave owner's). Nelson, drawing on Hilary McD. Beckles, observes that slaves in Barbados were sometimes punished by being forced to wear metal collars around their neck or legs. The collars were inscribed with the master's and maker's name and place of residence, which highlighted the fact that the slaves were regarded as property. According to Nelson, "The metal collars would have had a visceral and psychic effect on the slaves, stripping them of their humanity through the public spectacle of their collared bodies." 78

While the metal collar envelops the throat down which alcohol slides upon consumption, the slave mask covers the very orifice through which alcohol and dirt enter the body. Although Bridgens attempts to show in Bed-Stocks for Intoxication that the punishment did indeed have a physical impact on the slaves (despite the fact that in his text he refers to the "care taken" for the prisoners), in his representations of the androgynous figure in the mask and the woman wearing the collar there is a conspicuous docility and lack of obvious discomfort. Surely Bridgens chose to represent the figures holding still rather than visibly struggling with the objects of punishment that they are wearing because it was simply easier to do so. But this strange impression of stillness functions to erase any suggestion of resistance. Indeed, the figures could be said to be modelling the objects. There is even a small smile on the woman's face, thereby suggesting to the viewer that she was a willing participant in the project. Her expression and the tilt of her head are signifiers borrowed from the history of Western art, which is replete with posing women. Bridgens does not explicitly refer to resistance in his text. Likewise, the images, not surprisingly, are void of any human agency. Bridgens was a man of his time, and a slaveholder to boot. I would suggest that in identifying acts of resistance as addictions on the one hand, and as diseases on the other, Bridgens usurps his subjects of their agency, just as his images represent them as willing models for devices of punishment.

\section{Framing Acts of Resistance: Disease and Addiction}

In his description of Bed-Stocks for Intoxication, Bridgens refers to slaves who were "addicted to the unaccountable propensity of dirt-eating." The term "addiction" in relation to alcohol did not come into popular usage until the early twentieth century, so it is not surprising that Bridgens did not identify slaves' drunkenness as an addiction. Janet Farrell Brodie and Marc Redfield have observed that the first entry in the Oxford English Dictionary in which addiction refers to drug use is from 1906, and its first entry using "addict" as a noun was written in 1909.79 In
Latin, "addict" refers to a slave or bondsman who is "formally made over or bound (to another)." 80 Bridgens, writing in 1836, would not have been drawing so much on religious or medical texts concerned with alcohol consumption, but would likely have been aware of the etymology of the term "addicted," and he would have been using it in order to suggest that slaves who ate dirt were bound or controlled by the act itself.

As I have argued, slaves' dirt-eating was not an addiction that controlled them, but rather an act that they consciously chose based on, not in spite of, the self-destructive risks. I would suggest that Bridgens's use of the term reveals his ignorance regarding the behaviour, which is clearly indicated by his inclusion of the word "unaccountable," and that it was an attempt to frame the act in such a way as to position it as a behavioural oddity offered to his white British readers. I use the term "frame" here deliberately because I wish to emphasize that Bridgens's choice of words, his textual gesture, is discursive and representational. It is comparable to the way that nineteenthcentury European curators would have exhibited a non-Western object in an ethnographic museum as a grotesque curiosity. ${ }^{81}$ Bridgens also uses this framing strategy in his discussion of Negro Heads, with Punishments for Intoxication and Dirt-eating when he writes, "The mask is used as a punishment and preventative of the practice of dirt-eating, a disease peculiar to the Negro, and for which no satisfactory cause has been hitherto assigned." The author not only identifies dirt-eating as a disease, he also calls attention to his own lack of knowledge about the behaviour when he observes that "no satisfactory cause has been hitherto assigned" to the act. I believe that Bridgens, in not understanding the acts of resistance that he observed or heard about, framed them as both a disease and an addiction in order to offer a kind of uninformed explanation to both himself and his readers, because many nineteenth-century Britons were well-versed in discourses related to disease and addiction. ${ }^{82}$

A similar representational gesture is apparent in white slaveholders' attempts to comprehend and explain why slaves continually ran away. This apparent incomprehension is even more striking than Bridgens's lack of understanding about dirteating, because, while Bridgens may well have been unaware of the paradoxical motivations for eating dirt, surely slaves' reasons for wishing to escape from bondage were ludicrously obvious. Yet it appears that this was not so. In an article on runaway slaves in the plantation South, John Hope Franklin and Loren Schweninger demonstrate that in an effort to explain why slaves ran away one writer attributed it to "some disease, a "monomania'...to which the negro race is peculiarly subject." 83 This statement recalls Bridgens's observation that dirt-eating was "a disease peculiar to the Negro," which, in fact, was not the case. ${ }^{84}$ In 1851, Dr. Samuel Cartwright coined the term "drapetomania," which derived from the Greek words for runaway slave 
and madness, and he used it to describe "the disease causing negroes to run away." 85 Later in the century, some medical professionals discussed drug addiction employing words such as "morphinomania," thereby linking addiction with madness. ${ }^{86}$ Cartwright believed that running away from slavery was "as much a disease of the mind as any other species of mental alienation." 87 Dr. Thomas Trotter, among others, identified chronic drunkenness as a disease of the mind in the early nineteenth century. ${ }^{88}$ I suggest that some Britons and Americans used disease and addiction as framing devices to explicate slaves' acts of resistance because they could grasp these concepts in a way that they could not grasp any behaviours that demonstrated a slave's power to act with agency and choice.

Within the context of transatlantic slavery the possibilities for slaves to exert control over their own bodies were limited, but as I have shown, acts of consumption were both perceived and embraced as potential acts of resistance. The gaps and inconsistencies in Bridgens's text, and the conflicting accounts in West India Scenery and other nineteenth-century texts regarding the punishment of slaves, underscore the failures of many white Europeans to accurately represent, both textually and visually, slaves' experiences of resistance and punishment. If this latter aspect of slavery was not exactly unrepresentable, surely it could be claimed that it was, and continues to be, incomprehensible.

\section{Acknowledgments}

I am extremely grateful to the Social Sciences and Humanities Research Council of Canada for a Postdoctoral Fellowship that provided me with the time to revise this article for publication. I am indebted to Janice Helland, Kristina Huneault, and John Potvin for their guidance and support. My thanks also to David Mitchell for checking a source and to RACAR's anonymous reviewer whose insightful comments and suggestions have been greatly appreciated.

\section{Notes}

1 Much of my discussion is informed by Charmaine Nelson's work on race and visual culture. See, for example, Charmaine Nelson, Through An-Other's Eyes: White Canadian Artists, Black Female Subjects (Oshawa, 1998).

2 Charlotte Sussman, Consuming Anxieties: Consumer Protest, Gender, and British Slavery, 1713-1833 (Stanford, 2000), 5. The Abolition of the Slave Trade Bill was carried in the British House of Commons and House of Lords in 1807, but slavery continued nonetheless. British parliament passed the Slavery Abolition Act in 1833 . The Act was limited in its impact, because it only prevented Britons from importing new slaves from Africa. After the Act had passed, British slave owners began to be more attentive to "breeding" their female slaves in order to increase the number of slaves they "owned." See Charmaine Nelson, Representing the Black Female Subject in Western Art (New York and London, 2010), 44.

3 In addition to the images that I examine in this article (figs. 1 and 2), there are two other representations of punishments in West India Scenery, which both appear in the same plate. In the upper half of Stocks for Hands and Feet, with Bed and Hand Stocks, (from the approved Models) a black man is depicted standing with his arms stretched out in front of him and his hands and feet locked into stocks. In the lower half of the plate is the figure of a black woman wearing a white headwrap; she is seated on a wooden bedlike structure with her feet in stocks. I do not discuss these images in detail because I am concerned with the relationship between punishment, acts of resistance, and discourses of addiction and disease, and Stocks for Hands and Feet with Bed and Hand Stocks do not lend themselves to this discussion.

4 Judy Raymond is currently working on a biography of Bridgens. See Nicholas Laughlin, "The Talented Mr Bridgens," The Caribbean Review of Books, 8 Dec. 2010, http://caribbeanreviewofbooks.com/ 2010/12/08/the-talented-mr-bridgens/, last accessed 14 February 2011.

5 Laughlin, "The Talented Mr Bridgens."

6 Judy Raymond, "Out of Sight," The Caribbean Review of Books, Nov. 2010, http://caribbeanreviewofbooks.com/crb-archive/24...2010/ out-of-sight/, last accessed 14 February 2011.

7 Judy Raymond, "The Final Passage of Richard Bridgens," unpublished paper, Painting the Caribbean symposium, University of Essex, 6-7 May 2011.

8 Marcus Wood, "John Gabriel Stedman, William Blake, Francesco Bartolozzi and Empathetic Pornography in the Narrative of a Five Years Expedition against the Revolted Negroes of Surinam, "An Economy of Colour: Visual Culture and the Atlantic World, 1660-1830, ed. Geoff Quilley and Kay Dian Kriz (Manchester and New York, 2003), 132.

9 Wood, "John Gabriel Stedman,” 134.

10 Kay Dian Kriz, Slavery, Sugar, and the Culture of Refinement: Picturing the British West Indies, 1700-1840 (New Haven, 2008), 73.

11 Gillian Forrester, "The Ethnological Image," Art and Emancipation in Jamaica: Isaac Mendes Belisario and his Worlds, ed. Tim Barringer, Gillian Forrester, and Barbaro Martinez-Ruiz (New Haven, 2007), 460-61; Kriz, Slavery, Sugar, and the Culture of Refinement; Jeremy MacClancy, "Earthy Realism: Geophagia in Literature and Art," Consuming the Inedible: Neglected Dimensions of Food Choice, eds. Jeremy MacClancy, Jeya Henry, and Helen Macbeth (New York, 2007), 232.

12 Ducôte was active between 1830 and 1840 as a lithographer and lithographic printer. His name is associated with 156 portraits in the National Portrait Gallery, London, England. Belgium-born Haghe (1806-85) was regarded as one of the most important lithographers of his period. He travelled to London in the 1820s, and 
lived in England until his death. Haghe met Day, a printer and an Englishman, in London, and "Day \& Haghe" appeared in the London directories for the first time in 1833, although their firm may have opened as early as 1829 . In 1837 , they were appointed lithographers to Queen Victoria (they were not the only lithographers to receive this honour). Day died in 1845, at which point the firm became known as "Day \& Son." Haghe left the firm in 1852 to focus on watercolour painting. Bridgens's choice of lithographers says something about his high artistic aspirations for West India Scenery.

13 See Albert Boime, The Art of Exclusion: Representing Blacks in the Nineteenth Century (Washington and London, 1990).

14 Raymond has remarked, 'I've even been able to put tentative names to a couple of the slaves in his pictures." Laughlin, "The Talented Mr Bridgens."

15 Richard Bridgens, West India Scenery, with Illustrations of Negro Character, the Process of Making Sugar, etc. from Sketches taken during a Voyage to, and Residence of Seven years in, the Island of Trinidad (London, 1836), non-paginated.

16 For a discussion on the importance of headwraps for African women within the context of slavery and representation, see Nelson, "Tying the Knot: Black Female Slave Dress in Canada," Representing the Black Female Subject, 88-102. See also Steeve O. Buckridge, The Language of Dress: Resistance and Accommodation in Jamaica, 1760-1890 (Kingston, Jamaica, 2004).

17 See Beth Fowkes Tobin, Picturing Imperial Power: Colonial Subjects in Eighteenth-Century British Painting (Durham, 1999).

18 Boime, The Art of Exclusion, xiv.

19 Kriz, Slavery, Sugar, and the Culture of Refinement, 131.

20 Quoted in Kriz, Slavery, Sugar, and the Culture of Refinement, 131.

21 Jerome S. Handler and Annis Steiner, "Identifying Pictorial Images of Atlantic Slavery: Three Case Studies," Slavery and Abolition 27, 1 (2006): 58-59; MacClancy, "Earthy Realism," 232; Marcus Wood, Blind Memory: Visual Representations of Slavery in England and America 1780-1865 (New York and London, 2000), 225.

22 Nelson, Representing the Black Female Subject, especially chapters 3, 4, and 5; Michael Hatt, "Making a Man of Him': Masculinity and the Black Body in Mid-Nineteenth-Century American Sculpture," Race-ing Art History: Critical Readings in Race and Art History, ed. Kymberly N. Pinder (New York and London, 2002), 191-213; Wood, Blind Memory.

23 Charlotte Sussman, Consuming Anxieties, 42.

24 Stephanie M.H. Camp, Closer to Freedom: Enslaved Women and Everyday Resistance in the Plantation South (Chapel Hill and London, 2004), 87-88.

25 Kriz, Slavery, Sugar, and the Culture of Refinement, 131.

26 MacClancy reproduces only this detail rather than the whole plate. MacClancy, "Earthly Realism,” 232.

27 Elizabeth Kowaleski-Wallace, Consuming Subjects: Women, Shopping and Business in the Eighteenth Century (New York, 1997), 7.
28 Camp, Closer to Freedom, 3-4.

29 See Camp, Closer to Freedom, 62. See also Michael D. Harris, Colored Pictures: Race and Visual Representation (Chapel Hill and London, 2003), 33.

30 Camp, Closer to Freedom, 90.

31 Susan Zieger, Inventing the Addict: Drugs, Race, and Sexuality in Nineteenth-Century British and American Literature (Amherst, 2008), 79.

32 Sussman, Consuming Anxieties, 8.

33 David T. Courtwright, Forces of Habit: Drugs and the Making of the Modern World (Cambridge, MA, 2001), 30.

34 Sussman, Consuming Anxieties, 42.

35 Quoted in Sussman, Consuming Anxieties, 112.

36 Rosemary Betterton, "'A Perfect Woman': The Political Body of Suffrage," An Intimate Distance: Women, Artists and the Body (New York and London, 1996), 58.

37 Bridgens, West India Scenery, non-paginated.

38 Kriz, Slavery, Sugar, and the Culture of Refinement, 131.

39 Wood, Blind Memory, 225.

40 Quoted in Handler and Steiner, "Identifying Pictorial Images of Atlantic Slavery," 58. Arago's book was originally published in 1822 without the image.

41 Handler and Steiner, "Identifying Pictorial Images of Atlantic Slavery," 58.

42 Marietta Morrissey has described suicide and self-mutilation as "political acts" for some slaves, observing that "the historical literature offers examples of women engaging in these forms of resistance." Marietta Morrissey, Slave Women in the New World: Gender Stratification in the Caribbean (Lawrence, Kansas, 1989), 155. See also Terri L. Snyder, "Suicide, Slavery, and Memory in North America," The Journal of American History 97, 1 (2010): 39-62.

43 Wood, Blind Memory, 216.

44 My thanks to $R A C A R$ 's reviewer for elucidating this aspect of the punishment for me.

45 Kriz, Slavery, Sugar, and the Culture of Refinement, 129.

46 MacClancy, "Earthy Realism," 232.

47 Marcus Wood, The Horrible Gift of Freedom: Atlantic Slavery and the Representation of Emancipation (Athens and London, 2010).

48 Wood, The Horrible Gift of Freedom, 16.

49 Zieger, Inventing the Addict, 131.

50 See Anne Anderson, "'Chinamania': Collecting Old Blue for the House Beautiful, c. 1860-1900," Material Cultures, 1740-1920: The Meanings and Pleasures of Collecting, ed. John Potvin and Alla Myzelev (Aldershot, 2009), 109-28; Pamela K. Gilbert, Disease, Desire, and the Body in Victorian Women's Popular Novels (Cambridge, 1997); Kowaleski-Wallace, Consuming Subjects; Sussman, Consuming Anxieties.

51 Ralph Barnes Grindrod, Bacchus: An Essay on the Nature, Causes, Effects, and Cure of Intemperance, 2nd ed. (London, 1843), 14.

52 Grindrod, Bacchus, 15. Emphasis in the original. 
53 For a discussion that challenges the ostensible legibility of addiction from the body, see Julia Skelly, Wasted Looks: Addiction and British Visual Culture, 1751-1919, forthcoming from Ashgate.

54 Grindrod, Bacchus, 4.

55 Grindrod, Bacchus, 41.

56 Camp, Closer to Freedom, 78.

57 Camp, Closer to Freedom, 87.

58 Camp, Closer to Freedom, 68.

59 Camp, Closer to Freedom, 87-88.

60 Quoted in Camp, Closer to Freedom, 71.

61 Gilbert, Disease, Desire, and the Body, 46.

62 Camp, Closer to Freedom, 90.

63 Camp, Closer to Freedom, 2.

64 Camp, Closer to Freedom, 89-90.

65 John Gabriel Stedman, Narrative of a Five Years Expedition against the Revolted Negroes of Surinam in Guiana on the Wild Coast of South America; from the Year 1772-1777, vol. 2 (London, 1806), 56. Emphasis added.

66 I am grateful to $R A C A R$ 's reviewer for encouraging me to pursue this point further.

67 Wood, Blind Memory, 226.

68 Bridgens, West India Scenery, non-paginated.

69 Wood, Blind Memory, 221.

70 See Handler and Steiner, "Identifying Pictorial Images of Atlantic Slavery," 60.

71 Quoted in Handler and Steiner, "Identifying Pictorial Images of Atlantic Slavery," 59.

72 See Handler and Steiner, "Identifying Pictorial Images of Atlantic Slavery," 61.

73 Quoted in Handler and Steiner, "Identifying Pictorial Images of Atlantic Slavery," 59.

74 Morrissey, Slave Women in the New World, 151.

75 Wood, Blind Memory, 221.

76 My thanks to RACAR's reviewer for pointing this out.

77 See Wood, Blind Memory.

78 Nelson, Representing the Black Female Subject, 205, n. 6. See also Hilary McD. Beckles, "An Economic Life of their Own: Slaves as Commodity Producers and Distributors in Barbados," Caribbean Slavery in the Atlantic World, ed. Verene A. Shepherd and Hilary McD. Beckles (Kingston, Jamaica, 2000), 736-38.

79 Janet Farrell Brodie and Marc Redfield, "Introduction," High Anxieties: Cultural Studies in Addiction, ed. Janet Farrell Brodie and Marc Redfield (Berkeley, 2002), 2.

80 Zieger, Inventing the Addict, 6.

81 For a text that addresses some of the challenges of exhibiting the visual culture of slavery, see Douglas Hamilton and Robert J. Blyth, eds., Representing Slavery: Art, Artefacts and Archives in the Collections of the National Maritime Museum (Aldershot and Burlington, 2007). See also Wood, Blind Memory.

82 See Skelly, Wasted Looks; Zieger, Inventing the Addict.
83 Quoted in John Hope Franklin and Loren Schweninger, "The Quest for Freedom: Runaway Slaves and the Plantation South," Slavery, Resistance, Freedom, ed. Gabor Boritt and Scott Hancock (Oxford, 2007), 38.

84 MacClancy, "Earthy Realism," 232.

85 Quoted in Franklin and Schweninger, "The Quest for Freedom," 38.

86 See, for example, T.S. Clouston, "Diseased Cravings and Paralysed Control: Dipsomania; Morphinomania; Chloralism; Cocainism," Edinburgh Medical Journal 35, 2 (March 1890): 793-94.

87 Quoted in Franklin and Schweninger, "The Quest for Freedom," 39.

88 Thomas Trotter, An Essay, Medical, Philosophical, and Chemical on Drunkenness and its Effects on the Human Body (New York and London, 1988). Originally published in 1804. 